moving downstream. The amplitude of the waves is $1-2 \mathrm{~cm}$ and the wavelength $\sim 10 \mathrm{~cm}$. The film is stable and self-sealing. When a Plexiglass base of a cylinder is immersed at a high angle to the film plane, 1-3 faint surfaces parallel to the film, extending up to $2-3 \mathrm{~cm}$ above it, are observed.

We injected a lipophylic dye, Sudan III, into the saline layer just below the film and observed that the dye did not cross the film but spread laterally along it, forming a visible, yellowish film. In a period of $10-20 \mathrm{~s}$ the film gradually lost its artificial colour.

We expect that the film affects several estuarine processes. (1) It stabilizes the density gradient by diminishing vertical turbulent mixing of fresh water and saline water, and also damps the interfacial waves. (2) It should affect energy- and masstransport processes across the interface, analogously to the film at the air/water interface. (3) It should affect transformation of particles and solutes as all of the suspended material entering the estuary passes through the interface. Because residence time of particles in the interface is larger than elsewhere in the water column $^{25,26}$ (vertical transport is the smallest), particles and solutes have more time to interact with the organic matter. The interactions such as flocculation, complexation and sorption have half times in minutes ${ }^{25,27-29}$. All of these processes are fast enough to affect the particles crossing the interface. Mineral particles that sink across the film acquire organic coatings ${ }^{16,30}$ and transport the film material to the deeper layer ${ }^{26}$ whereas light organic particles are accumulated on the film. (4) Organic matter retained in the interface and on the film represents a potential food source for heterotrophic organisms. The film also acts as a scavenger (trap) of pollutants ranging from mercury to chlorinated hydrocarbons ${ }^{6,17}$. It might thus represent a site for pollutant incorporation into food chains.

We thank S. Macura, Ž. Kwokal and K. Pregernik for underwater sampling and observations; M. Najdek for pigment analysis; Dr. G. Cauwet for POC analysis; Z. Gržetić for hydrographical data; and Dr. J. Marston for improving the manuscript. This research is supported by the Authority for Science Research of SR Croatia, Yugoslavia and UNEP/IOC (Mediterranean Trust Fund).

Received 18 February; accepted 11 May 1987

1. MacIntyre, F. in The Sea, Vol. 5 (ed. Goldberg, E. D.) 245-299 (Wiley, New York, 1974) 2. Hunter, K. A. \& Liss, P. in Marine Chemistry (eds Dursma, K. E. \& Dawson, R.) 259-298 (Elsevier, Amsterdam, 1981).

3. Stumm, W. \& Morgan, J. J. Aquatic Chemistry (Wiley, New York, 1981).

4. Ketchum, B. H. Estuaries and Enclosed Seas, Ecosystems of the world Vol. 23 (Elsevier, Amsterdam, 1983)

5. Retray, M. Jr \& Mitsuda, E. Estuar. Coast mar. Sci 2, 375-394 (1974)

6. Žutić, V Long-Term Research and Pollution Monitoring of the Krka Estuary and Kornati Archipelago (Adriatic Sea), MED POL-Phase II (Center for Marine Research, R. Bošković Institute, Zagreb, Annual reports, 1983-86)

7. Zvonarić, T., Žutić, V. \& Branica, M. Thalassia jugosl. 9, 65-75 (1973)

8. Žutić, V., Cosović, B., Bihari, N., Marčenko, E. \& Kršinić, F. Mar. Chem. 10, 505-520 (1981)

9. Hunter, K. A. \& Liss, P. Water Res. 15, 203-215 (1981).

10. Žutić, V., Pleše, T., Tomaić, J. \& Legović, T. Molec. Cryst. Liq. Cryst. 113, 131-145 (1984)

11. Pleše, T. \& Żutić, V. J, electroanaly' Chem. 175, 299-312 (1984)

12. Kennedy, V. S. (ed.) The Estuary as a Filter (Academic, Orlando, 1984).

13. Juračić, M. thesis, Univ. of Zagreb (1987)

14. Hunter, K. A. \& Liss, P. Limnol. Oceanogr. 25, 807-822 (1980)

15. Hunter, K. A. Geochim. cosmochim. Acta 47, 467-473 (1983)

16. Žutić, V., Cauwet, G. \& Monaco, A. in Proc. 7th Workshop on Marine Pollution of the Mediterranean, Luzern, 1984, 173-180 (UNEP, 1986).

17. Martinčić, D., Branica, M. \& Kwokal, Ż. in Long-Term Research and Pollution Monitoring of the Krka Estuary and Kornati Archipelago (Adriatic Sea), MED POL.Phase II (Center for Marine Research, R. Bošković Institute, Zagreb, Annual reports, 1983-86).

18. Tanford, C. The Hydrophobic Effect (Wiley, New York, 1980).

19. Istraelachvili, J. N. \& Pasey, R. M. J. Colloid Interface Sci. 98, 500-514 (1984).

20. Staehelin, L. A. \& Arntzen, C. J. in Chloroplast Organization and Energy Transfer in Photosynthesis (ed. Porter, G.) 147-175 (Ciba Foundation Symposium No. 61, Amsterdam, 1978)

21. D'Arrigo, J. S., Saiz-Jimenez, C. \& Reiner, N. S. J. Colloid Interface Sci. 100, 96-105 (1984).

22. D’Arrigo, J. S. J. Colloid Interface Sci. 100, 206-111 (1984).

23. Berger, W. R. \& Means, J. C. in Marine and Estuarine Geochemistry (eds Sigelo, A. C. \& Hattori, A.) 47-67 (Lewis, Chelsea, 1985).
Hat

24. Mueller, P., Rudin, D. O., Tien, T. H. \& Wescott, W. C. Nature 194, 979-980 (1962).

25. Sakamoto, W. Bull. Ocean. Res., Inst. Univ. Tokyo, 5, 1-49 (1972)

26. Alösi, J. C. et al. Oceanol. Acta 5, 481-491 (1982)

27. Mayer, L. M. Geochim. cosmochim. Acta 46, 1527-1536 (1982)

28. Raspor, B., Nuernberg, N. W. Valenta, P. \& Branica, M. Limnol Oceanogr. 26, 54-66 (1981)

29. Harwey, R. W Lion, L. W. Young. Y. \& Leckie, J. L J mar. Reanogr. 26, 54-66 (1981)

30. Żutić, V. \& Tomaić, J. Mar. Chem. (in the press)

31. Ćosović, B., Žutić, V. \& Cauwet, G. 28th CIESM Meeting, Cannes (November, 1983).

\section{Localization of the gene for familial adenomatous polyposis on chromosome 5}

\author{
W. F. Bodmer*, C. J. Bailey*, J. Bodmer ${ }^{\dagger}$, \\ H. J. R. Bussey \\ F. C. Lucibello*, V. A. Murday , S. H. Rider\|, \\ P. Scambler\#, D. Sheer\|, E. Solomon** \\ \& N. K. Spurrt†
}

* Director's Laboratory, $†$ Tissue Antigen, ${ }^{* *}$ Somatic Cell Genetics and || Human Cytogenetics Laboratories, Imperial Cancer Research Fund, Lincoln's Inn Fields, London WC2A 3PX, UK

$\$$ Polyposis Registry, I ICRF Colorectal Unit, St Mark’s Hospital, City Road, London ECIV 2PS, UK

$\S$ Gastroenterology Unit, Broadgreen Hospital, Liverpool L14 3LB, UK

\# Department of Biochemistry, St Mary`s Hospital Medical School, London W2 1 PG, UK

$\dagger$ Human Genetic Resources Laboratory, ICRF Clare Hall

Laboratories, Blanche Lane, South Mimms, Potters Bar,

Hertfordshire EN6 3LD, UK

Colorectal cancer is the second most common cancer in the United Kingdom and other developed countries in the West. Although it is usually not familial, there is a rare dominantly inherited susceptibility to colon cancer, familial adenomatous polyposis (FAP; also of ten previously called familial polyposis coli). During adolescence affected individuals develop from a few hundred to over a thousand adenomatous polyps in their large bowel. These are sufficiently likely to give rise to adenocarcinomas to make prophylactic removal of the colon usual in diagnosed FAP individuals. Adenomas may occur elsewhere in the gastrointestinal tract and the condition is often associated with other extracolonic lesions, such as epidermoid cysts, jaw osteomata and fibrous desmoid tumours ${ }^{1-4}$. Adenomata have been suggested to be precancerous states for most colorectal tumours ${ }^{5,6}$. Knudson ${ }^{7}$ has suggested that the mutation for a dominantly inherited cancer susceptibility may be the first step in a recessive change in the tumour cells, and that the same gene may be involved in both familial and non-familial cases of a given tumour. Following up a case report of an interstitial deletion of chromosome 5 in a mentally retarded individual with multiple developmental abnormalities and $F A P^{8}$, we have now shown that the FAP gene is on chromosome 5, most probably near bands $5 q 21-q 22$.

Most of the families for the study were identified by the Polyposis Register at St Mark's Hospital, London and by the Gastroenterology Unit, Broadgreen Hospital, Liverpool, and were well characterized with respect to clinical, pathological and pedigree information. Sterile blood samples were collected from these families and lymphocytes separated out and frozen. These were subsequently transformed by Epstein-Barr virus (EBV) to produce a permanent source of DNA (ref. 9). The sediment of these mononuclear cell separations was also used to provide an immediate source of DNA (Fig. 1 legend). Five polymorphic DNA probes (see legends to Figs 1 and 2) assigned to chromosome 5 and mostly not regionally localized, were tested on up to 124 members from 13 different families. One of

Table 1 Lod scores from two-point analyses for linkage between C11p11, L1.4 and FAP

\begin{tabular}{lccccc} 
& \multicolumn{5}{c}{ Recombination fraction $(\theta)$} \\
Marker loci & 0.0 & 0.10 & 0.20 & 0.30 & 0.40 \\
C11p11-FAP & 3.26 & 2.56 & 1.88 & 1.15 & 0.44 \\
L1.4-FAP & -2.50 & 0.78 & 0.66 & 0.37 & 0.12 \\
\hline
\end{tabular}



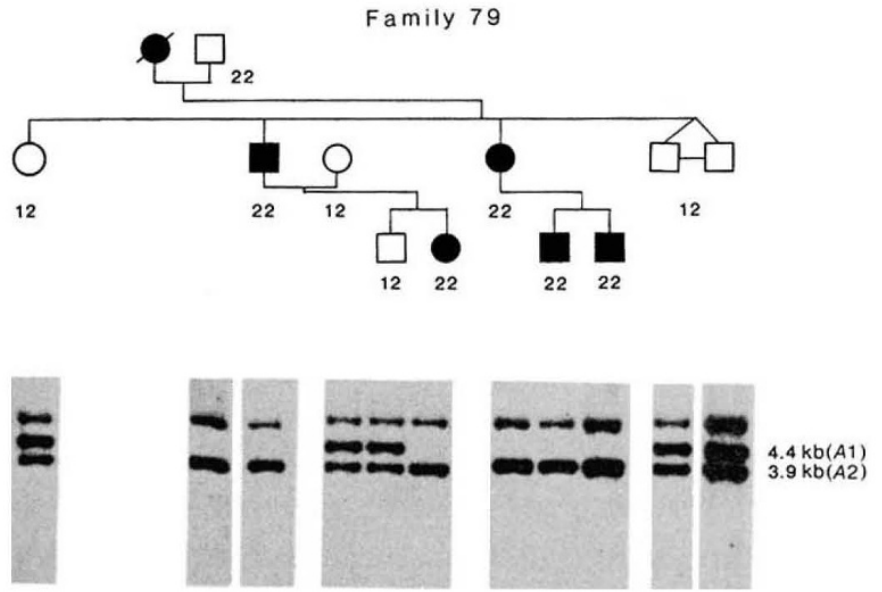

Fig. 1 Family 79 demonstrating segregation of FAP with a 3.9-kb fragment using the probe $\mathrm{C} 11 \mathrm{p} 11$, a 3.6-kb Eco RI fragment cloned into pUC8 that reveals a TaqI polymorphism producing alleles $A 1$ at $4.4 \mathrm{~kb}$ and $A 2$ at $3.9 \mathrm{~kb}$. Symbols: $\square$, male; $\bigcirc$, female; solid symbol, affected individuals.

Methods. Blood samples were collected from family members and lymphocytes separated and frozen for future transformation with EBV (ref. 9). DNA of high relative molecular mass was extracted from both the residue of the separation and from the transformed lymphocytes. The cells were lysed in a solution containing $0.33 \mathrm{M}$ sucrose, $5 \mathrm{mM} \mathrm{MgCl}, 10 \mathrm{mM}$ Tris- $\mathrm{HCl} p \mathrm{H} \mathrm{7.5,} \%$ Triton X-100. Nuclei were pelleted at $8,000 \mathrm{~g}$ at $4{ }^{\circ} \mathrm{C}$ for $10 \mathrm{~min}$ and resuspended in $75 \mathrm{mM} \mathrm{NaCl}, 25 \mathrm{mM}$ EDTA, $200 \mu \mathrm{g} \mathrm{ml}^{-1}$ proteinase $\mathrm{K}$ and $0.5 \%$ SDS. The mixture was incubated overnight at $37^{\circ} \mathrm{C}$. The aqueous phase was extracted three times in phenol buffered with $2 \mathrm{mM}$ Tris and $2 \mathrm{mM}$ EDTA and once in isoamyl alcohol: chloroform $(1: 24)$. The DNA was reprecipitated with $1 / 10 \mathrm{vol}$. $3 \mathrm{M}$ sodium acetate $p \mathrm{H} 5.2$ and two vols absolute alcohol and then resuspended in TE. Aliquots $(10 \mu \mathrm{g})$ of genomic DNA were digested overnight with 50 units of restriction enzyme, under the recommended conditions (TaqI digests for 4-6h). The samples were run in $0.8 \%(\mathrm{w} / \mathrm{v})$ agarose gels for $36-48 \mathrm{~h}$, at $1-1.5 \mathrm{~V} \mathrm{~cm}^{-1}$. The gels were depurinated in $0.25 \mathrm{M} \mathrm{HCl}$ for $10 \mathrm{~min}$, denatured in $\mathrm{NaOH}$ for $45 \mathrm{~min}$ and then neutralized for $60 \mathrm{~min}$. The DNA was then transferred to Hybond- $\mathrm{N}$ nylon filters (Amersham), following the manufacturer's recommendation. Probes were labelled with $\left[\alpha-{ }^{32} \mathrm{P}\right] \mathrm{dCTP}$ by the oligolabelling method ${ }^{17}$ for $4-6 \mathrm{~h}$ at $37^{\circ} \mathrm{C}$. The filters were prehybridized in $6 \times$ SSC, $0.1 \%$ SDS, $5 \times$ Denhardt's solution containing $25 \mu \mathrm{g} \mathrm{ml}^{-1}$ of denatured salmon sperm DNA for $1-2 \mathrm{~h}$ at $65^{\circ} \mathrm{C}$. Hybridization was carried out overnight at $65^{\circ} \mathrm{C}$ in the same solution but supplemented with

$10 \mu \mathrm{Ci} \mathrm{m}^{-1}$ of labelled probe and $10 \%$ dextran sulphate.

the probes, C11p11 (provided by the Department of Biochemistry, St Mary's Hospital, London), showed evidence for close linkage to FAP. This probe reveals a TaqI polymorphism, producing alleles of 3.9 kilobases $(\mathrm{kb})$ and $4.4 \mathrm{~kb}$ with frequencies of about 0.92 and 0.08 (based on 53 individuals, see Fig. 1). Six of the families, including 79 typed individuals, were informative and these gave a combined maximum lod score of 3.26 at a recombination fraction of $\theta=0$, using the LIPED linkage analysis computer program ${ }^{10}$. The lod scores for the linkage of FAP to L1.4 (DSS4) (ref. 11) are also given and, although not significant, give an estimate for the recombination fraction $\theta$ of about 0.1 (see Table 1). The other probes (L1.7 (D5S1) (ref. 11) from P. Pearson; $\lambda$ MS8 from A. Jeffreys (ref. 12) and pHexXbal, a hexosaminidase B probe from R. Gravel) showed no significant linkage with FAP or with each other. There was no obvious heterogeneity between the families with respect to the linkage of $\mathrm{C} 11 \mathrm{p} 11$ with FAP. Assigning the most probable genotypes in all cases and assuming close linkage, the data are consistent with no recombinants amongst 24 meioses, with no genotype predictions being necessary in 12 out of these 24 meioses.

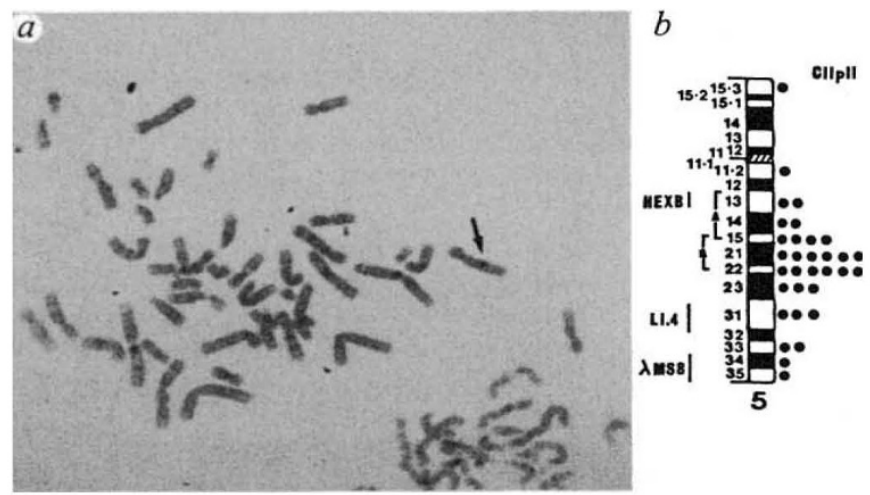

Fig. $2 a$, Representative chromosome spread showing in situ hybridization of probe $\mathrm{C} 11 \mathrm{p} 11$. In situ hybridization was performed on chromosomes prepared from PHA-stimulated normal blood lymphocytes essentially as described by Harper and Saunders ${ }^{18}$. Probe C11p11 was labelled by random oligonucleotide priming and ${ }^{3} \mathrm{H}$-deoxyribonucleotides to a specific activity of $1 \times$ $10^{7}$ c.p.m. $\mu \mathrm{g}^{-1}$. Slides were washed in $2 \times \mathrm{SSC}$ at $39^{\circ} \mathrm{C}$, dehydrated and dipped in Ilford K-5 emulsion. They were developed after 10 days. $b$, Fine chromosome mapping of probe C11p11 and putative regional assignment of probes L1.4 and $\lambda$ MS8. Fine chromosome mapping was carried out with the $\mathrm{C} 11 \mathrm{p} 11$ probe; 221 silver grains were scored on chromosomes from 150 metaphases, with 22 grains (9.9\%) present over bands $5 q 15-q 23$ and most over bands 5q21-22. Preliminary data for in situ hybridization of the L1.4 probe localizes it to band 5q31. Localization of $\lambda$ MS8 was by in situ hybridization (N. J. Royle and A. J. Jeffreys, personal communication). The symbols $\boldsymbol{\Delta}$ and the associated regions represent the two alternative positions for the interstitial deletion reported by Herrera et al. ${ }^{8}$ L1.7 ( $D S S 1$, ref. 10) is a 1.14-kb EcoRI fragment cloned into pBR322 and reveals a $B g I I I$ polymorphism with alleles $A 1$ at $7.9 \mathrm{~kb}$ and $A 2$ at $10.6 \mathrm{~kb}$. L1.7 also reveals a $P s t I$ polymorphism with alleles $B 1$ at $2.8 \mathrm{~kb}$ and $B 2$ at $2.3 \mathrm{~kb}$. L1.4 (DSS4, ref. 10 ) is a $0.72-\mathrm{kb} E c o$ RI fragment cloned into pBR322 and reveals an EcoRI polymorphism with alleles $A 1$ at $0.7 \mathrm{~kb}$ and $A 2$ at $0.6 \mathrm{~kb}$. L1.4 also reveals an RsaI polymorphism with alleles $C 1$ at $2.4 \mathrm{~kb}$ and $C 2$ at $2.2 \mathrm{~kb}$ (ref. 19). Probe $\lambda$ MS8 (ref. 11) produces multiple alleles with Hinft. Probe pHexXbaI (ref. 10) is a $1.5-\mathrm{kb} \mathrm{XbaI}$ cDNA fragment from the hexosaminidase $\mathrm{B}$ gene, cloned into pSP64. A $1.1-\mathrm{kb}$ Bam HI-PstI fragment reveals a Pst I polymorphism with alleles $A 1$ at $1.6 \mathrm{~kb}$ and $A 2$ at $1.0 \mathrm{~kb}$.

To relate the linkage data to the interstitial deletion reported by Herrera et $\mathrm{al}^{8}{ }^{8}$, in situ hybridization was carried out to localize C11p11 and L1.4 on chromosome 5. Probe C11p11 localizes to 5q21-q22 (Fig. 2a) which is consistent with the deletion described by Herrera et al. being at 5q15-q22 rather than their cytogenetically indistinguishable alternative 5q13-q15. This localization is also consistent with a case report of a large bowel adenocarcinoma which has a 5q12?-q22 deletion in addition to other cytogenetic abnormalities ${ }^{13}$. The lack of significant linkage between $H E X B$ or $\lambda$ MS 8 and FAP is consistent with their having been localized on the long arm of chromosome 5 (Fig. $2 b$ ). In the case of L1.4 this may be due to the small number of informative families rather than its location.

The demonstration in the accompanying paper ${ }^{14}$ that $>20 \%$ of sporadic colorectal carcinomas become homo- or hemizygous for chromosome 5 alleles, the appreciable lod score for linkage with C11p11 and the coincidental localization of the probe with the two deletion $\mathrm{s}^{8,13}$ provides overwhelming evidence for assigning FAP to chromosome 5, probably to 5q21-q22.

The marker loss data, together with the localization of FAP, extend Knudson's ideas to FAP and, at least, to a major subset 
of colorectal carcinomas. The data thus suggest that becoming recessive for a gene around $5 \mathrm{q} 21-\mathrm{q} 22$ is a key step in the progression of many colorectal carcinomas, both sporadic and familial. The fact that polyps from FAP patients do not yet show the recessive change, as shown in the accompanying paper ${ }^{14}$, is consistent with data using G6PD markers which suggested that polyps were not clonal ${ }^{15}$.

One possible explanation for how heterozygosity for a deficiency can give rise to localized growth abnormalities such as polyps, is through a threshold effect involving, for example, negative control over the production of growth factors. In this model, the normal homozygote produces enough of the FAP gene product so that random fluctuations of its concentration never, or at least only very rarely, go below a threshold that permits localized excessive growth. The deficient heterozygote, however, may allow random fluctuations in the level of the FAP gene product to go below this threshold relatively frequently. In those areas of the colon where this happens, excessive epithelial growth may be initiated, giving rise to polyps. Once initiated, this growth may persist by, for example, some form of feedback control for production of a growth factor. This is at least one way to explain how a gene dosage effect can give rise to discontinuous growths, namely the polyps, which look as though they should be clonal. Presumably the polyps, once they have arisen, provide the opportunity for the second, recessive, change to take place, followed no doubt by other changes which lead to the overt carcinoma.

The apparent similarity in frequency of FAP throughout the world, together with the relatively high proportion of cases (up to $40 \%$ ) which may be sporadic, due to new mutations ${ }^{1}$, suggests that most FAP families may carry different mutations. At this detailed genetic level the disease may therefore be quite heterogeneous. The incidence of FAP is estimated to be at least $1 / 10,000$ and perhaps up to $1 / 5,000$, which suggests that the mutation rate to FAP is at least $1 / 100,000$ and could be as high as $1 / 25,000$. Perhaps there are sequences around the FAP gene which predispose it to relatively high mutation rates.

Now that the FAP gene has been localized, long-range DNA analysis using pulsed field gel electrophoresis and chromosome jumping techniques ${ }^{16}$, together with searches for appropriate epithelial-specific messages encoded in this genetic region, should lead to the identification of the FAP gene and its function. This will not only provide a basis for the presymptomatic or prenatal diagnosis of FAP, but may also lead to approaches to counter-acting the FAP defect and provide new clues to specific treatments for at least some forms of sporadic colon carcinoma.

The following centres and individuals collaborated in this study by providing family samples and probes; we thank them for their cooperation and hard work. Steven Bryant, Human Genetics Resources Laboratory, ICRF Clare Hall Laboratories; Dr R. Cartwright, Mrs J. Greatrex, Mrs P. Roberts, Dr L. Williams, the Leukaemia Research Fund Centre for Clinical Epidemiology, Leeds University, Leeds; Dr R. Gravel, Hospital for Sick Children, Toronto, Canada; Dr A. Jeffreys, Department of Genetics, University of Leicester; Lorna Kennedy and Steve Marsh, Tissue Antigen Laboratory, Imperial Cancer Research Fund, London; Paul A. Lawson, Director's Laboratory, ICRF, London; Dr C. McKeown and Professor R. H. Harris, Department of Medical Genetics, St Mary's Hospital, Manchester; Dr P. L. Pearson, Department of Human Genetics, State University, Leiden, The Netherlands; Dr B. Ponder, Institute of Cancer Research, Royal Marsden Hospital, Sutton; Dr S. Ritchie and Miss K. Neale, Polyposis Registry, St Mark's Hospital, London; Sister J. Shaw, Gastroenterology Unit, Broadgreen Hospital, Liverpool.

Received 22 June; accepted 21 July 1987

1. Bulow, S. Dan. med. Bull. 34, 1-15 (1987)

2. Veale, A. M. O. Intestinal Polyposis (Cambridge University Press, 1965).

3. Bussey, H. J. R. Familial Polvposis Coli (Johns Hopkins University Press, 1975).
4. Gardner, E. Am. J. hum, Genet. 3, 167-176 (1951).

5. Muto, T., Bussey, H. J. R. \& Morson, B. C. Cancer, 36, 2251-2270 (1975).

6. Morson, B. C. Clin. Radiol. 35, 425-431 (1984).

7. Knudson, A. G. Jr Proc. natn. Acad. Sci. U.S.A. 68, 820-823 (1971)

8. Herrera, L., Kakati, S., Gibas, L., Pietrzak, E. \& Sandberg, A. A. Am. J. med. Genet. 25, 473-476 (1986)

9. Miller, G. \& Lipman, M. Proc. natn. Acad. Sci. U.S.A. 70, 190-194 (1973).

10. Ott, J. Am. J. hum. Genet. 20, 588-597 (1974).

11. 8th Int. Workshop on Human Gene Mapping Cytogenet. Cell Genet. 40, 1-824 (1985).

12. Wong, Z et al. Ann, hum Genet, (in the press).

13. Ferti-Passantonopolou, A., Panani, A., Avgerinos, A. \& Raptis, S. Cancer Genet. Cytogenet. 21, 361-364 (1986).

14. Solomon, E. et al. Nature 328, 616-619 (1987)

5. Hsu, S. H., Luk, G. D., Krush, A. J., Hamilton, S. R. \& Hoover, H. H. Jr Science, 221, 951-953 (1983).

16. Poustka, A., Pohl, T. M., Barlow, D. P., Frischauf, A. \& Lehrach, H. Nature 325, 353-355 (1987)

17. Feinberg, A. P. \& Vogelstein, B. Analyt. Biochem. 132, 6-13 (1983).

18. Harper, M. E. \& Saunders, G. F. Chromosoma 83, 431-439 (1981).

19. Bailey, C. J., Rider, S. H. \& Bodmer, W. F. Nucleic Acids Res. (in the press).

\section{Chromosome 5 allele loss in human} colorectal carcinomas

E. Solomon*, R. Voss †, V. Hall*, W. F. Bodmer J. R. Jass $\S$, A. J. Jeffreys $\|$, F. C. Lucibello $\ddagger$, I. Patel\| \& S. H. Rider $\|$

* Somatic Cell Genetics Laboratory, $\ddagger$ Director’s Laboratory, I. Human Cytogenetics Laboratory, Imperial Cancer Research Fund, Lincoln's Inn Fields, London WC2A 3PX, UK

+ Department of Human Genetics, Hadassah Medical School, Jerusalem, Israel

$\S$ St Mark's Hospital, City Road, London EC1V 2PS, UK

|| Department of Genetics, University of Leicester,

Leicester LE1 7RH, UK

That the sporadic and inherited forms of a particular cancer could both result from mutations in the same gene was first proposed by Knudson ${ }^{1}$. He further proposed that these mutations act recessively at the cellular level, and that both copies of the gene must be lost for the cancer to develop ${ }^{2}$. In sporadic cases both events occur somatically whereas in dominant familial cases susceptibility is inherited through a germline mutation and the cancer develops after a somatic change in the homologous allele. This model has since been substantiated in the case of retinoblastoma ${ }^{3}$, Wilms' tumour $^{4-7}$, acoustic neuroma ${ }^{8}$ and several other tumours ${ }^{9,10}$, in which loss of heterozygosity was shown in tumour material compared to normal tissue from the same patient. The dominantly inherited disorder, familial adenomatous polyposis (FAP, also called familial polyposis coli), which gives rise to multiple adenomatous polyps in the colon that have a relatively high probability of progressing to a malignant adenocarcinoma ${ }^{11}$, provides a basis for studying recessive genes in the far more common colorectal carcinomas using this approach. Following a clue as to the location of the FAP gene given by a case report of an individual with an interstitial deletion of chromosome $5 q$, who had FAP and multiple developmental abnormalities ${ }^{12}$, we have examined sporadic colorectal adenocarcinomas for loss of alleles on chromosome 5 . Using a highly polymorphic 'minisatellite' probe ${ }^{13}$ which maps to chromosome $5 q$ we have shown that at least $20 \%$ of this highly heterogeneous set of tumours lose one of the alleles present in matched normal tissue. This parallels the assignment of the FAP gene to chromosome 5 (see accompanying paper ${ }^{14}$ ) and suggests that becoming recessive for this gene may be a critical step in the progression of a relatively high proportion of colorectal cancers.

Tumour material and adjacent normal mucosa samples were collected from about 45 cases of colorectal carcinomas, mostly from St Mark's Hospital, London. DNA preparations from these matched normal-tumour pairs were analysed for restriction fragment length polymorphism (RFLP) differences with a variety of probes that had been assigned to particular chromosomes. Following the clue that the FAP gene might be on chromosome 5 , attention was concentrated on probe $\lambda$ MS8 (ref. 13) which 